\title{
Effects of nipple or bucket feeding of milk-substitute on rumen by-pass and on rate of passage in calves
}

\author{
BY M. ABE, T. IRIKI, K. KONDOH AND H. SHIBUI \\ Laboratory of Nippon Formula Feed Manufacturing Co., \\ 4-I-I Higashiterao, Tsurumi-ku, Yokohama 230, Japan
}

(Received 25 April 1978 - Accepted 10 July 1978)

I. Effects of feeding liquid milk-substitute to young calves either by nipple-pail or open-bucket on the rumen by-pass and on the rate of passage were studied.

2. Sixteen Holstein calves, aged I week initially, were used in three experiments in which calves were slaughtered after they were given liquids (milk-substitute and water) containing chromic oxide and $\mathrm{SrCl}_{2} \cdot 6 \mathrm{H}_{2} \mathrm{O}$ as a tracer either by the nipple- or bucket-feeding method, and the distribution of tracers to the rumen, abomasum and the lower alimentary tracts was examined.

3. When the liquid milk-substitute containing tracers was given by the nipple- or bucket-feeding method to calves having been trained to the corresponding procedures for the preceding I week, most of the tracers was directed into the omasum and abomasum. There seemed no difference in the functioning of oesophageal groove closure between the two feeding procedures. Even when the liquid milk-substitute containing tracers was given by the nipple-or bucket-feeding method to calves which had been accustomed to different procedures for the preceding week, the majority of tracers were found in the abomasum immediately after administration, though a slightly greater proportion of the tracers entered the reticulo-rumen.

4. Continuing bucket feeding of liquid milk-substitute effected an efficient closure of the oesophageal groove at least up to 16 weeks of age. After calves were accustomed to consume liquid milk-substitute from the bucket from I to 4 weeks of age, drinking warm water from the bucket also caused efficient closure at least up to 16 weeks of age.

5. When tracers were administered with warm water, $\mathrm{Cr}_{2} \mathrm{O}_{3}$ and strontium, especially the latter, transferred much more rapidly to the lower gut than when they were administered with liquid milk-substitute, probably reflecting the curd formation of the milk-substitute in the abomasum. When liquid milk-substitute with tracers was fed by the bucket-feeding method, $\mathrm{Sr}$ transferred more rapidly to the lower gut than when the milk-substitute was fed by the nipple-feeding method, indicating that the feeding procedure of liquid milk-substitute has an apparent effect on the rate of passage.

Milk-substitutes have been used in many intensive farms as the means of reducing cost of rearing calves. Feeding procedures of the liquid milk-substitute are divided into two main classes: the nipple-feeding method and the bucket-feeding method. The nipple-feeding method has been considered to be more adequate for young calves from the physiological aspect than the bucket-feeding method, in view of earlier work which showed that the reflex closure of the oesophageal groove depended on the stimuli associated with sucking milk from a teat (Wise \& Anderson, 1939) or on the posture of calves while sucking (Wise et al. I942). However, the bucket-feeding method has been adopted by large numbers of Japanese farmers because of its simplicity.

Subsequently, Hegland et al. (1957) observed a complete closure of the oesophageal groove of calves during 6 weeks after birth, independently of the feeding procedure and the type of liquid fed. More recently, Ørskov et al. (1970), working with lambs, concluded that the reflex closure of the groove does not depend on the chemical and mechanical stimuli associated with sucking milk from dams or from a nipple bottle. Then, is there no difference between nipple feeding and bucket feeding? The purpose of the present studies was to investigate further the similarity or discrepancy in effects of both feeding procedures on the digestive physiology of young calves. 


\section{EXPERIMENTAL}

\section{Milk-substitute}

The milk-substitute used in three experiments consisted of $(\mathrm{g} / \mathrm{kg}): 650$ skim-milk, Ioo dried whey-powder, 90 glucose, 150 spray-dried fat premix, $5 \mathrm{Na}_{3} \mathrm{PO}_{4} \cdot 12 \mathrm{H}_{2} \mathrm{O}, 4$ vitamin-antibiotic premix and I trace mineral premix, and contained ( $\mathrm{g} / \mathrm{kg}$ dry matter) 282 crude protein (nitrogen $\times 6.25$ ) and $\mathrm{I} 35$ diethyl ether extract. The fat premix contained $800 \mathrm{~g}$ tallow (homogenized and stabilized) $/ \mathrm{kg}$. The vitamin-antibiotic premix contained $(/ \mathrm{kg}): 150 \mathrm{mg}$ retinol, $2.5 \mathrm{mg}$ cholecalciferol, $50 \mathrm{~g}$ DL- $\alpha$-tocopheryl acetate and $6.25 \mathrm{~g}$ colistin sulphate (Kyowa Hakko Industrial Co., Tokyo). The mineral premix consisted of $(\mathrm{g} / \mathrm{kg}): 320 \mathrm{KCl}$, $240 \mathrm{MgSO}_{4} \cdot 7 \mathrm{H}_{2} \mathrm{O}, 80 \mathrm{Na}_{2} \mathrm{SO}_{4}, 30 \mathrm{FeSO}_{4} \cdot 7 \mathrm{H}_{2} \mathrm{O}, 28 \mathrm{ZnSO}_{4} \cdot 7 \mathrm{H}_{2} \mathrm{O}, 8 \mathrm{MnCO}_{3}, 2 \mathrm{KI}$ and $290 \mathrm{CaCO}_{3}$.

Expt I. Eight Holstein male calves were used in Expt I. All calves were less than $45 \mathrm{~kg}$ initial body-weight, and were considered not to exceed $7 \mathrm{~d}$ of age. They were divided into two groups of four calves each. One group was given 3.21 of a warm solution containing $400 \mathrm{~g}$ milk-substitute daily by the nipple-pail for I week. Another group was accustomed to the bucket feeding of an equal quantity of the liquid milk-substitute for the same period. Calves received half the quantity of milk-substitute at 08.30 hours and the other half of 16.30 hours, and were not given access to any solid food or drinking water. On the 8th day, all calves were killed immediately after they were given $\mathrm{I} \cdot 61$ liquid milk-substitute containing $4 \mathrm{~g}$ chromic oxide and $\mathrm{I} 2 \mathrm{~g} \mathrm{SrCl} \mathrm{S}_{2} \cdot 6 \mathrm{H}_{2} \mathrm{O}$ as a tracer for the distribution of milk-substitute in various digestive organs. The final liquid milk-substitute feed containing tracers was fed by the nipple-feeding method to two calves in each of the nipple- and bucket-feeding groups, and fed by the bucket-feeding method to the remaining two calves in both groups.

Expt 2. Four Holstein male calves aged approximately I week were used. They were given 3.21 warm solution containing $400 \mathrm{~g}$ milk-substitute daily at $\mathrm{I}$ week of age and then 3.61 warm solution containing $600 \mathrm{~g}$ milk-substitute daily from 2 to 4 weeks of age; both feeds were fed by the bucket-feeding method, half the quantity at 08.30 hours and half at 16.30 hours. One group of two calves was weaned after 5 weeks of age, and each calf received 1.81 of warm water by the bucket-feeding method at 08.30 hours and I6.30 hours from 5 to 16 weeks of age. The remaining two calves were successively bucketfed $\mathrm{x} .81$ of the liquid milk-substitute at 08.30 hours and $\mathrm{I} 6.30$ hours until the end of their I6th week. Roughage (Bermuda grass (Cynodon dactylon (L.) PERS.) hay) and concentrate (pelleted calf-starter; crude protein $(\mathrm{N} \times 6.25), \mathrm{I} 90 \mathrm{~g} / \mathrm{kg})$ were offered $a d$ lib. to all calves throughout the experiment. All calves received additional restricted amounts of cold water after 5 weeks of age from buckets at $\mathrm{I} 2.00$ hours every day according to the following schedule: 5-8 weeks of age, 41;9-12 weeks of age, 81; 13-16 weeks of age, I2 1. At the end of the 8th and the I6th week, one calf from each group was killed at 11.30 hours, $3 \mathrm{~h}$ after bucket feeding of either the liquid milk-substitute or warm water both containing $5 \mathrm{~g}$ $\mathrm{Cr}_{2} \mathrm{O}_{3}$ and ${ }_{15} \mathrm{~g} \mathrm{SrCl}_{2} .6 \mathrm{H}_{2} \mathrm{O} / \mathrm{I} \cdot 8 \mathrm{I}$.

Expt 3. Four Holstein male calves aged approximately $\mathrm{I}$ week were divided into two groups of two calves each. One group was given 3.21 warm solution containing $400 \mathrm{~g}$ milk-substitute daily at $\mathrm{I}$ week of age and then 3.61 warm solution containing $600 \mathrm{~g}$ milksubstitute daily from 2 to 4 weeks of age, both feeds given by the nipple-feeding method, half the quantity at 08.30 hours and half at I6.30 hours. Another group was given the same daily amounts of the liquid milk-substitute by the bucket-feeding method at the same time of day until the end of 4 weeks of age. Calves were not given access to any solid food or drinking-water throughout the experiment. At the end of their 4 th week, all calves were killed $4 \mathrm{~h}$ after they were given the last liquid milk-substitute containing $5 \mathrm{~g} \mathrm{Cr}_{2} \mathrm{O}_{3}$ 

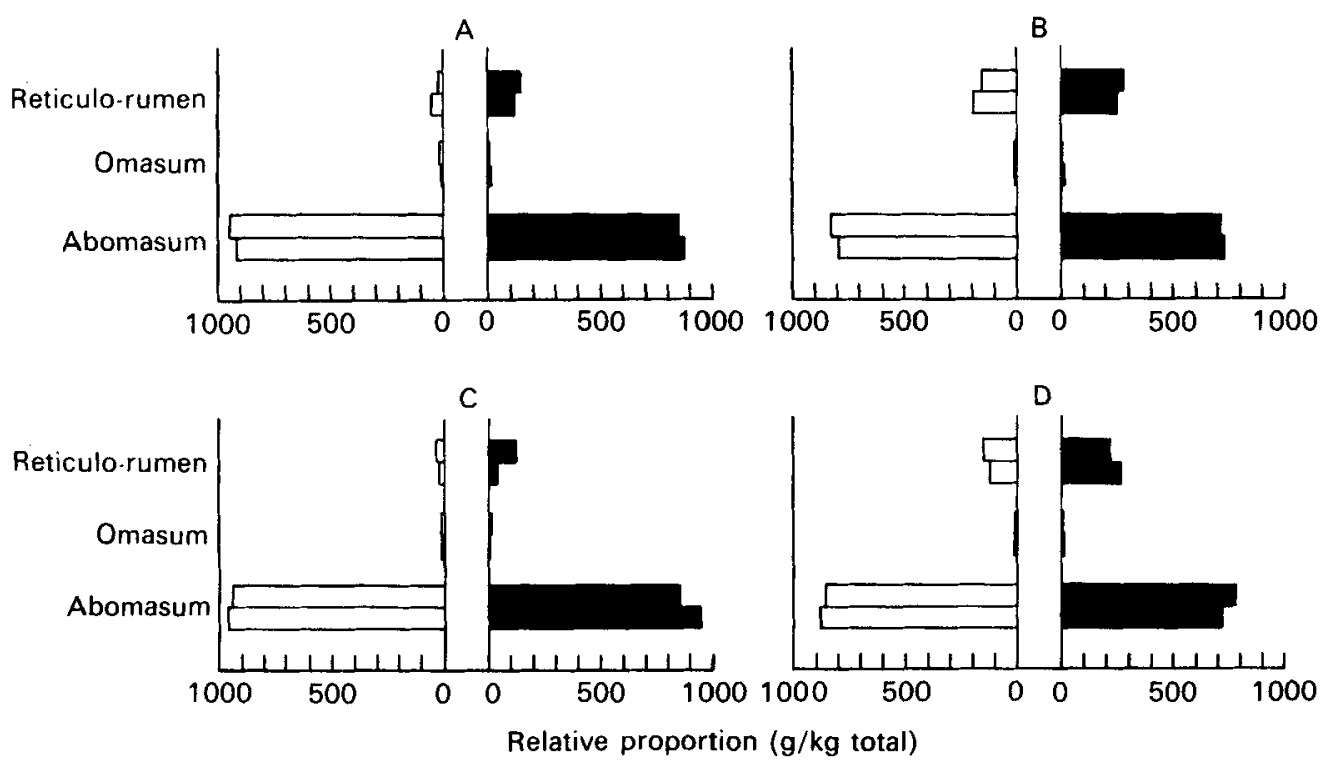

Fig. I. Relative proportions of $\mathrm{Cr}_{2} \mathrm{O}_{3}(\square)$ and strontium ( $(\mathbf{D})$ distributed to the reticulo-rumen, omasum and abomasum of 2-week-old calves immediately after the feeding of liquid milksubstitute containing tracers. The final milk-substitute feed was (A) nipple- or (B) bucket-fed to calves trained to the nipple-feeding method for I week, and (C) bucket- or (D) nipple-fed to calves trained to the bucket-feeding method for 1 week. For details of feeds and procedures, see p. 176 .

and $15 \mathrm{~g} \mathrm{SrCl}_{2} \cdot 6 \mathrm{H}_{2} \mathrm{O} / \mathrm{I} \cdot 8 \mathrm{l}$, either by the nipple-feeding method to the nipple-fed group or by the bucket-feeding method to the bucket-fed group.

\section{Analyses}

Immediately after slaughter, the alimentary canal was separated into its individual digestive parts. But the rumen and reticulum were treated as one section, and the jejunum and ileum were not separated but divided into three portions of equal length. The contents of each section were collected and dried at $75^{\circ}$. The $\mathrm{Cr}_{2} \mathrm{O}_{3}$ content of the dried samples of digesta from each section of the gut was determined as described previously by Abe $e t$ al. (1976). Strontium was determined by atomic absorption spectroscopy as described by Hedde \& Ward (1973) using a two-wavelength atomic absorption spectrophotometer (model 308; Hitachi Ltd, Minato-ku, Tokyo).

\section{RESULTS}

Expt I. Fig. I shows the distribution of $\mathrm{Cr}_{2} \mathrm{O}_{3}$ and $\mathrm{Sr}$ in the whole stomach of calves slaughtered immediately after the feeding by the various procedures of liquid milk-substitute with tracers. When the milk-substitute with tracers was given to calves by the same methods as those to which they had been trained for I week before slaughter, more than $95 \%$ of the $\mathrm{Cr}_{2} \mathrm{O}_{3}$ and more than $85 \%$ of the $\mathrm{Sr}$ found in the stomach were recovered from the abomasum and, to a considerably lesser extent, from the omasum. When the milk-substitute with tracers was fed by different methods from those to which calves had been accustomed for the preceding I week, more than $85 \%$ of the $\mathrm{Cr}_{2} \mathrm{O}_{3}$ and more than $70 \%$ of the $\mathrm{Sr}$ in the stomach were found in the abomasum and omasum. Though calves were slaughtered immediately after the administration of tracers, slight but not negligible amounts of tracers 


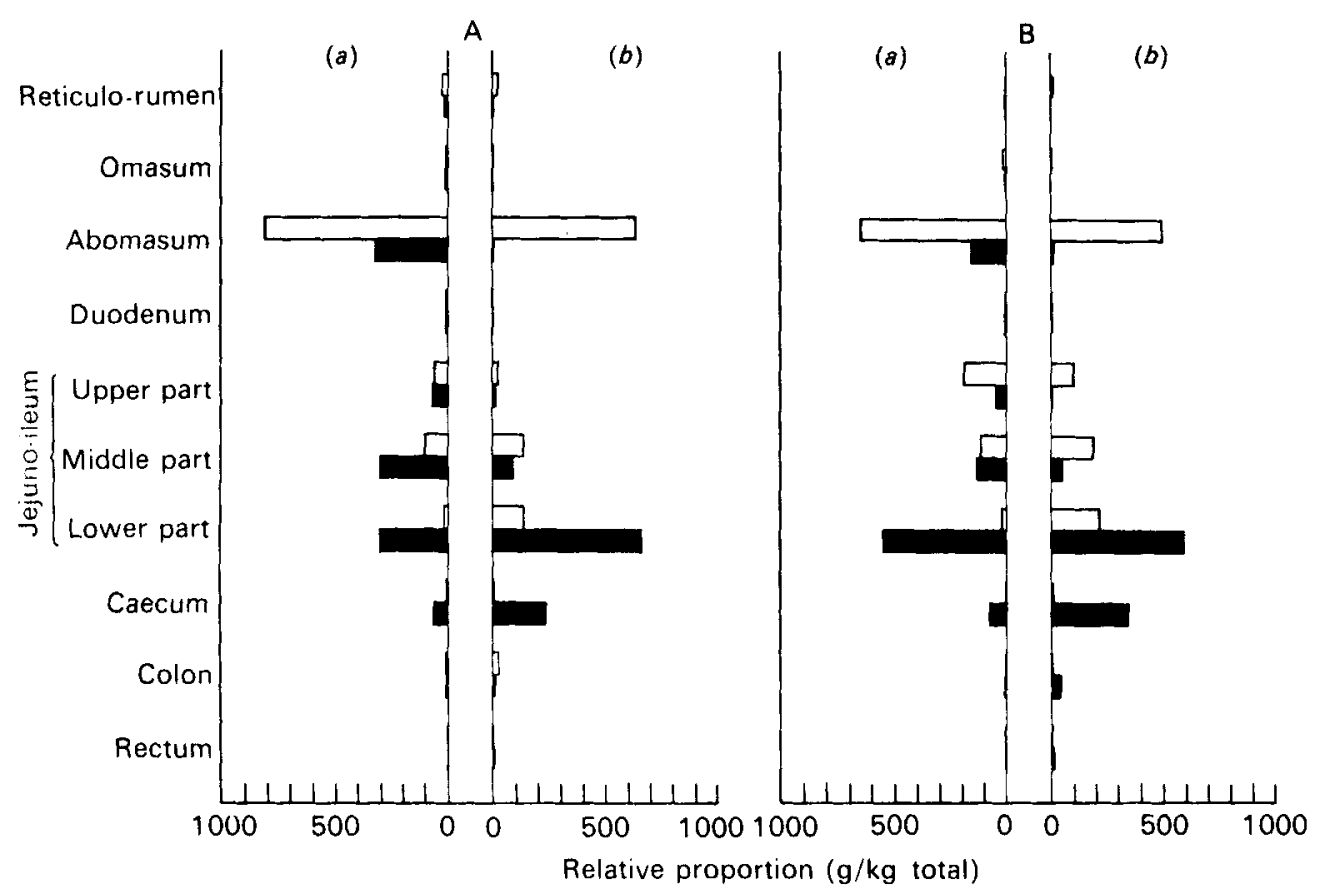

Fig. 2. Relative proportions of $\mathrm{Cr}_{2} \mathrm{O}_{3}(a)$ and strontium $(b)$ distributed to the stomach and alimentary tracts $3 \mathrm{~h}$ after the feeding of liquid milk-substitute ( $\square$ ) or warm water ( $\mathbf{a})$ containing tracers both by the bucket-feeding method (A) at 8 weeks and (B) at 16 weeks of age. For details of feeds and procedures, see p. 176.

were recovered from the upper part of the small intestine. If the latter amounts were taken into account, the relative proportion of tracers directed to the abomasum was somewhat higher than that shown in Fig. I for each feeding procedure.

Expt 2. Fig. 2 shows the distribution of $\mathrm{Cr}_{2} \mathrm{O}_{3}$ and $\mathrm{Sr}$ in various digestive organs of calves slaughtered $3 \mathrm{~h}$ after the morning feeding of liquid milk-substitute or warm water containing tracers by the bucket-feeding method at 8 and 16 weeks of age. Independent of the age and the type of liquid, substantially all the tracers existed posterior to the reticulo-rumen. One important finding was the obvious difference in the distribution patterns between liquids with which tracers were administered. When tracers were administered with water, $\mathrm{Cr}_{2} \mathrm{O}_{3}$ and $\mathrm{Sr}$, especially the latter which was administered as a soluble salt, transferred much more rapidly to the lower gut than when they were administered with liquid milk-substitute. At the slaughter, the curd formation which was never observed in calves receiving warm water, was observed in the abomasum of calves receiving milk-substitute.

Expt 3. Fig. 3 shows the distribution of $\mathrm{Cr}_{2} \mathrm{O}_{3}$ and $\mathrm{Sr}$ in various digestive organs of calves slaughtered $4 \mathrm{~h}$ after the feeding of liquid milk-substitute containing tracers by the nipplefeeding and by the bucket-feeding method. There was no obvious change in the distribution pattern of $\mathrm{Cr}_{2} \mathrm{O}_{3}$ between the two methods of feeding except in one calf which had diarrhoea from approximately io $\mathrm{d}$ before slaughter, and showed more rapid transference of $\mathrm{Cr}_{2} \mathrm{O}_{3}$ than the other animals. In the distribution pattern of $\mathrm{Sr}$, there was an apparent difference between the feeding procedures. The Sr transferred more rapidly to the lower gut in calves fed by the bucket-feeding method, especially in the calf with diarrhoea, than in calves fed by the nipple-feeding method. 


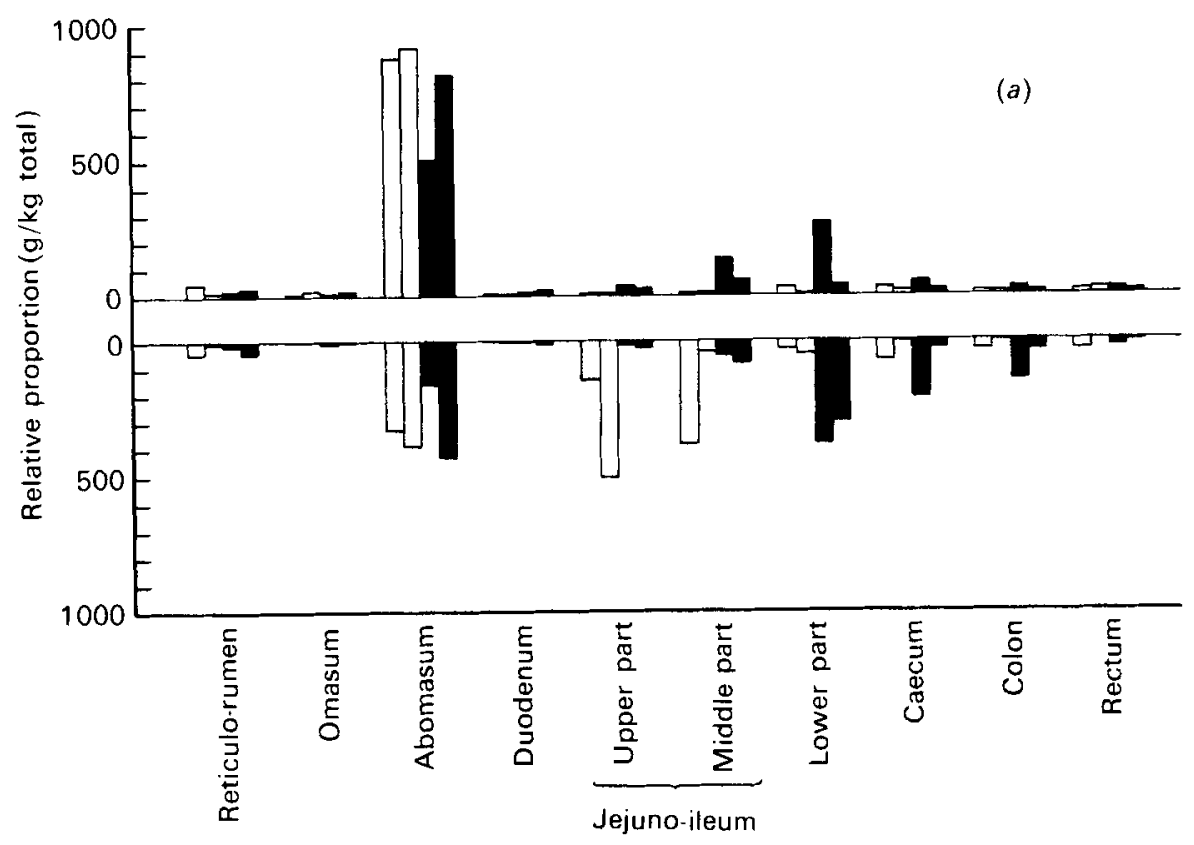

Fig. 3. Relative proportions of $\mathrm{Cr}_{2} \mathrm{O}_{3}(a)$ and strontium (b) distributed to the stomach and alimentary tracts $4 \mathrm{~h}$ after the feeding of liquid milk-substitute containing tracers either by the nipple-feeding method $(\square)$ or by the bucket-feeding method $(\boldsymbol{m})$. For details of feeds and procedures, see p. 176 .

\section{DISCUSSION}

The mortality of newborn calves from diarrhoea sometimes reaches $20 \%$ or more in Japanese farms. The incidence of diarrhoea is highest in milk-substitute-fed calves less than 3 weeks of age. In Expt I, the effect of the method of feeding milk-substitute to calves at 1-2 weeks of age on the rumen by-pass was examined. The results show that there was no difference in functioning of the groove reflex between the nipple-feeding method and the bucket-feeding method in 2-week-old calves, at least after they had been trained to the method for I week, and that even when the feeding procedure was abruptly altered the majority of the milk-substitute entered the abomasum though the reflex closure seemed to be slightly less effective. These observations are generally in good agreement with the results of earlier work (Hegland et al. 1957; Ørskov et al. 1970). Ørskov et al. (1970) demonstrated that in trained lambs the closure of the oesophageal groove occurred before drinking began, in response to a routine which signalled that a fluid meal was about to be given, suggesting that the reflex closure of the groove was elicited by appropriate visual, auditory or olfactory stimuli and no longer depended on stimulation of buccal and pharyngeal receptors during sucking and swallowing. Slightly insufficient closure of the groove observed in Expt $I$ when the feeding procedure was abruptly altered may represent a disorientation of calves untrained to a new procedure.

In Expt $\mathrm{I}$ and also in the successive experiments, tracers were more or less detected in the reticulo-rumen whether they were administered by the bucket- or nipple-feeding method to trained or untrained calves. The results seem to disagree with observations in previous studies in which the closure of the groove was assessed by examining the deposition of various sizes of gelatin capsules directly through the rumen fistula (Hegland et al. 1957), or the location of barium sulphate radiographically (Ørskov et al. I970; Lawlor et al. I97I). The use of $\mathrm{Sr}$ was developed as a convenient method to determine the efficacy of 
rumen by-pass by Hedde $\&$ Ward (1973). In all these earlier studies, a 'complete' closure of the oesophageal groove was reported. Lenkeit \& Columbus (1935) have suggested that some liquid may flow back from the abomasum to the reticulo-rumen. A similar finding was made in the present study, probably the result of shock accompanying slaughter, for some quantities of clotted milk-substitute as was seen in the abomasum were found in the reticulo-rumen of many calves. Nevertheless, it can never be denied that part of the tracers was introduced directly into the reticulo-rumen. And further the reason why the relative proportion of $\mathrm{Cr}_{2} \mathrm{O}_{3}$ entering the reticulo-rumen was different from that of $\mathrm{Sr}$ is also obscure. Recoveries of administered $\mathrm{Cr}_{2} \mathrm{O}_{3}$ and $\mathrm{Sr}$ from the stomach and lower alimentary tracts were more than $90 \%$ in all experiments.

Hegland et al. (1957) reported that nipple feeding effected a complete closure of the oesophageal groove for at least I 3 weeks of age, whereas bucket feeding of liquids, especially of water, was less effective after 6 weeks of age. In Expt 2, however, there was no evidence of a decrease in the efficiency of groove closure at least for 16 weeks of age even by the bucket-feeding method independent of the type of liquid. Neither the ad lib. feeding of solid food (roughage and concentrate) nor giving additional restricted amounts of cold water disturbed the reflex closure of the oesophageal groove at least up to 16 weeks of age.

When tracers were administered with water in Expt 2, $\mathrm{Cr}_{2} \mathrm{O}_{3}$ and $\mathrm{Sr}$, especially the latter, transferred much more rapidly to the lower gut than when they were administered with the liquid milk-substitute. The curd formation was observed in the abomasum of calves receiving milk-substitute, but was not observed in calves receiving water. The difference in the distribution pattern of tracers between liquids tested could be regarded as a reflection of whether the curd is formed in the abomasum or not. Expt 3 was conducted to examine whether the feeding procedure of liquid milk-substitute affects the distribution pattern of tracers in various digestive organs. The results suggested a higher passage rate in bucket-fed calves than in nipple-fed calves. This is probably caused by the difference between feeding procedures in time taken to consume a definite volume of liquid milksubstitute. In Expt I, half of the daily amount of liquid milk-substitute was drunk from a bucket within $40 \mathrm{~s}$ but was sucked from a nipple in 4-6 min by calves at I-2 weeks of age. The fact that calves drink much more rapidly from a bucket implies that much more milk-substitute reaches the abomasum at a time than it does in sucking calves. It may possibly affect the curd formation in the abomasum.

In a bucket-fed calf with diarrhoea, the transference of $\mathrm{Cr}_{2} \mathrm{O}_{3}$ and $\mathrm{Sr}$ to the lower gut was the most rapid. This may suggest that a higher rate of passage or a poor curd formation was the cause of diarrhoea in this calf, as was supposed by some workers (Roy, 1969; Radostits \& Bell, 1970). There seems to be a need for further research between the higher passage rate and the incidence of diarrhoea.

In conclusion, the reflex closure of the oesophageal groove occurs efficiently in 2-week-old calves independently of the feeding procedure (nipple-feeding method and bucket-feeding method) when they are trained to either method at least for I week, but it is evident that the feeding procedure of liquid milk-substitute has an influence on the rate of passage through the gut of calves.

The authors are grateful to Dr Y. Kunihisa of this laboratory for his helpful advice in the determination of strontium by atomic absorption spectroscopy. 


\section{REFERENCES}

Abe, M., Iriki, T., Kondoh, K. \& Kawai, T. (1976). Jap. J. Zootech. Sci. 47, 254.

Hedde, R. D. \& Ward, G. M. (I973). J. Dairy Sci. 56, 1567.

Hegland, R. B., Lambert, M. R., Jacobson, N. L. \& Payne, L. C. (I957). J. Dairy Sci. 40, 1007.

Lawlor, M. J., Hopkins, S. P. \& Kealy, J. K. (I97I). Br. J. Nutr. 26, 439.

Lenkeit, W. \& Columbus, A. (1935). Arch. wiss. prakt. Tierheilk. 69, 380.

Ørskov, E. R., Benzie, D. \& Kay, R. N. B. (I970). Br. J. Nutr. 24, 785.

Radostits, O. M. \& Bell, J. M. (I 970). Can. J. Anim. Sci. 50, 405.

Roy, J. H. B. (1969). Proc. Nutr. Soc. 28, I6o.

Wise, G. H. \& Anderson, G. W. (1939). J. Dairy Sci. 22, 697.

Wise, G. H., Anderson, G. W. \& Miller, P. G. (1942). J. Dairy Sci. 25, 529. 